\title{
SYMPOSIUM ON JEFFREY L. DUNOFF AND MARK A. POLLACK, “THE JUDICIAL TRILEMMA"
}

\author{
SYSTEMIC JUDICIAL AUTHORITY: THE “FOURTH CORNER” OF “THE JUDICIAL \\ TRILEMMA"? \\ Gleider Hernándę*
}

Jeffrey Dunoff and Mark Pollack's Judicial Trilemma ${ }^{1}$ is a refreshing challenge to prevailing narratives about judicial decision-making in international courts and tribunals and is part of a growing wave of scholarship deploying empirical, social science-driven methodology to theorize the place of judicial institutions in the international legal field. ${ }^{2}$ Seeking to peek behind the black robes and divine the reasoning behind judicial decisions without descending into speculation and actively trying to thwart considerations of confidentiality is a fraught endeavor on which I have expressed skepticism in the past. ${ }^{3}$ The Judicial Trilemma admirably seeks to overcome these challenges, and I commend the authors for tackling the hard question as to whether one can truly glance behind the black robe.

I started my academic career writing about judicial reasoning at the ICJ, seeking to explain the institutional, sociological, and structural factors which positioned that institution-a wider theoretical project that has since grown into a study of the social processes which constitute authority within the international legal process. But I also come to the domain having spent considerable time peeking behind the black robes themselves, both as a judicial clerk at the ICJ, and also as a special assistant to an investment arbitral tribunal. In this regard, I appreciate the challenges inherent in seeking to discern the "reality" of judicial decision-making and the obstacles of confidentiality and institutional loyalty that risk "contaminating" the data. Nevertheless, I will make two specific points in my comment on Dunoff and Pollack's commendable piece: first, in relation to some assumptions embedded in their methodological analysis; and secondly, reflections on what is perhaps the fourth "corner" that has not been addressed in their Trilemma, namely, the institutional or collective authority of the judicial institution in play.

\section{Methodological Questions}

The first methodological caveat relates to the fact that judges and arbitrators owe a degree of institutional loyalty. The issue arises because the preservation of the authority of the institution, or even of the legal system itself, can often be elided with that individual judge's concern over status and respect from his or her own peers, and may in some respects be contingent on the regard of those peers. ${ }^{4} \mathrm{I}$ am expressing here a concern with the design of the

* Associate Professor (Reader) in Public International Law, Durbam Law School.

${ }^{1}$ Jeffrey Dunoff \& Mark Pollack, The Judicial Trilemma, 111 AJIL 225 (2017).

2 See, e.g., Karen J. Alter, The New Terrain of International Law: Courts, Politics, Rights (2014); Yuval Shany, Assessing the EFFECtiveness of International Courts (2014).

3 See Gleider I. Hernández, The International Court of Justice and the Judicial Function 127 (2014).

${ }^{4}$ See id. at 106.

The American Society of International Law and Gleider Hernández (C) 2017. This is an Open Access article, distributed under the terms of the Creative Commons Attribution licence (http://creativecommons.org/licenses/by/4.0/), which permits unrestricted re-use, distribution, and reproduction in any medium, provided the original work is properly cited. 
Trilemma itself: I do not think that the design of the Trilemma takes sufficient notice of this fourth consideration, "institutional authority," in an institution's desire to preserve the secrecy of its deliberations. Perhaps institutional authority is a facet of judicial independence; but in many respects, it is sufficiently distinct from the independence of the individual judge. Dunoff and Pollack's concerns about the need for reelection, and about the possibility of dissenting or separate opinions, overwhelmingly emphasize the consequences for an individual judge, with insufficient emphasis on the consequences for the institution's authority. These exist, to my mind, in a mutually reinforcing process. ${ }^{5}$

The importance of institutional authority is buttressed by my second methodological observation, one that is acknowledged by the authors but perhaps requires greater emphasis, concerning the reliability of the evidence collected. This is a caveat related to the first: judges, arbitrators, and their supporting personnel are explicitly under a duty of confidentiality and loyalty to the institution. To speak publicly in such a manner as to demean the institution carries with it significant personal risk for the individual concerned, which will not be assumed lightly. For example, Dunoff and Pollack remark that the judges generally would not concede that reelection was a concern in their mind, and the judges emphasized that the proper discharge of their duties and the quality of their decision-making was paramount. ${ }^{6}$ In other words, the judges sought to depict themselves as above such pressures, and as committed to serving an international community in the pursuit of justice. The sceptic in me cannot help but wonder which judge would be glib enough to suggest otherwise, and in this regard, I welcome the fact that Dunoff and Pollack commented on the more forthright commentary of Sir Gerald Fitzmaurice and the anonymous former President of the ICJ, both of whom were more open about the anxieties and pressures created by a reelection system. Such concerns are particularly salient with respect to the authors' description of the emergence of the World Trade Organization (WTO) Appellate Body, and how its own members set about ensuring its autonomy as well as the judicialization of its internal procedure. ${ }^{7}$ As such, I applaud the authors for painstakingly embarking on a series of interviews and on gathering what is possibly the best evidence thus obtained in this regard, and would join them in cautioning against unhesitatingly accepting the views and arguments expressed by the interviewees, who have other strategic interests in play besides reelection.

Finally, Dunoff and Pollack are at their most cogent when elaborating on the concerns for judicial independence, and the structural threats to such independence posed by a court that is structured to privilege accountability and transparency. But I think, as they themselves concede, that they are somewhat caught in a U.S.-centric discourse of judicial politics, drawing analogies to a system that is structurally, institutionally, and culturally distinct from that of international law. ${ }^{8}$ Dunoff and Pollack make no apologies for this- they admit freely that the bulk of the "judicial politics" literature lies in the study of American federal courts? — but do not seem fully to appreciate the consequences of adopting such an approach. To this non-American international lawyer, there is something distinctly unusual in their methodology: because judicial institutions and their politics are understood so differently in different jurisdictions, the systemic context becomes of heightened importance. Let us take the point on judicial appointment. The process of judicial appointments, and the politics surrounding these in the United States, provides little guidance with respect to appointment to an international court, not least due to the difficulties in

${ }^{5}$ I have developed this idea in $\underline{i d}$. at ch. IV-V.

${ }^{6}$ Dunoff \& Pollack, supra note 1, at 257, citing José E. Alvarez, What Are International Judges for? The Main Functions of International Adjudication, in The Oxford Handbook of International Adjudication 158, 173 (Cesare Romano et al. eds., 2014).

${ }^{7}$ Dunoff \& Pollack, supra note 1 , at 260-71.

${ }^{8}$ See their own definition of judicial independence, $\underline{i d}$. at 231: “judicial politics scholars have extensively theorized and empirically studied the question of judicial independence, broadly defined as the ability of judges to decide cases free of extralegal pressures from outside actors."

${ }^{9}$ Id. at 233; see also discussion of the WTO, id. at 260-71. 
reconciling the vote of a state at a constituent assembly body (the UN General Assembly for the ICJ, the Assembly of States Parties at the International Criminal Court) to a judicial appointments process in the United States. The appointment processes are, whether in the United States or on the international plane, designed for different purposes, with different values at stake, involving different constituencies, and invariably employing a different procedure involving widely divergent categories of stakeholders. Besides the fact that they are all intended to determine the place of extralegal pressures and confine them, there is such a qualitative difference between these appointment processes - and between them and elections to regional courts, or courts in other domestic legal systems - that for all intents and purposes, they are entirely different methods of judicial selection. Regrettably, that concern is not explicitly addressed by the authors. Though one can remain certain that sociolegal American legal scholarship has much to contribute to scholarship on international courts and tribunals, it is my view that such scholarship is at its most effective when such insights are presented as culturally and institutionally contingent, and not as universal claims that can apply across cultures, institutions, and legal systems. The Judicial Trilemma is concerning to me in this regard; it is powerful because it is backed up by empirical evidence, but the metasupposition that American judicial political theory can be transposed into the realm of international judicial politics strikes me as slightly eccentric.

Institutional Design and Claims to Institutionalized Authority

Let us continue with a closer examination of the Judicial Trilemma. From the outset, there is a conundrum in the Judicial Trilemma, in its identification of the three core values of independence, accountability, and transparency as interlocking, mutually exclusive (to the extent that only two can be pursued, necessarily neglecting the third), and as values. Again, in the authors' own words, the Trilemma reflects potential trade-offs relating to three core values:

(1) judicial independence, the freedom of judges to decide disputes upon the facts and the law, free of outside influences such as the preferences of powerful states;

(2) judicial accountability, structural checks on the exercise of individual judicial authority manifested most prominently in international courts via reappointment processes; and

(3) judicial transparency, specifically mechanisms that permit the identification of individual judicial positions, primarily through the publication of separate votes or opinions. ${ }^{10}$

Dunoff and Pollack's introduction implies that, in the Judicial Trilemma, they have engaged with inductive and deductive methodologies in constructing their model. It is a normative model, in that they draw on sociological techniques of institutional design to describe the intentions of the states that created these judicial institutions. But it is, equally, a descriptive model that seeks to incorporate the finely-balanced considerations that individual judges must address when discharging their functions, as those emerged throughout the interview process and through further empirical work. In their own words,

$[\mathrm{u}]$ nderstanding the founding moments of design, however, tells only part of the story, because the actual workings of international courts, and the interactions among those dimensions, depend in large part on the actions of the judges who subsequently hear disputes, interpret the law, and issue rulings. For insights on how to conceptualize and understand international judicial behavior, we look beyond the scholarship on institutional design, and draw inspiration from the rich interdisciplinary literature on judicial politics. ${ }^{11}$

${ }^{10}$ Id. at 226.

11 Id. at 231. 
There is an inherent tension in this attempt to construct a theoretical model that simultaneously captures the design considerations of the founders of an institution (here, states), and the manner in which these are discharged by the judicial officials who subsequently carry out the functions attributed to them. Is it accurate to say that the concerns of an institution's founders necessarily become the predominant concern of the institution's agents or officials? And if not, is the Judicial Trilemma the intersection in a Venn diagram between the intentions of the drafters and the intentions of the judges? To my mind, there is a conflation between drafters' intentions, institutional considerations, and the priorities of the individual judges that goes unaddressed in this study but would merit further consideration.

The concern I have raised recurs throughout the article, and the authors have not separated the issues, generally preferring to juxtapose freely how states have amended the constituent instruments of international courts, and when judges have amended their rules of procedure. There are consequences, again, to this conflation. If one distinguishes between state-impelled changes, such as to term lengths and reelection proceedings, ${ }^{12}$ and courtimpelled changes such as the publication of dissenting opinions or the disclosure of voting, the contrasting concerns become somewhat clearer. As illustrated by Dunoff and Pollack's findings, state-led changes have leaned towards improving accountability or transparency, whilst judge-led modifications have oscillated between independence and transparency.

To give but two examples, first, when the European Convention of Human Rights was amended by states parties to provide longer, nonrenewable terms, thus buttressing their independence, the initiative was judge-led, with many decades elapsing before states would accept the need for such independence. ${ }^{13}$ Secondly, though the ICJ amended its Rules in the late 1970s to identify judges who voted for the majority judgment, thus shifting in favor of a higher degree of transparency, one must recall the context in which the ICJ had been operating: from 1963 to 1970, only one case was submitted, in 1967. This period coincided with the height of the Cold War but also with the Court's infamous judgment in South West Africa, ${ }^{14}$ which raised serious questions within the Non-Aligned Movement as to the Court's suitability to reflect the views of all states. ${ }^{15}$ It cannot be ignored that states' concerns would have impelled the judges' amendments to the ICJ Rules, but these contextual facts are left out of Dunoff and Pollack's otherwise thorough analysis. One could say the same about the evolution of the WTO Appellate Body's Working Procedures, in which the Appellate Body itself has emphasized the need for consensus in its decision-making, not so much out of a need to suppress transparency but a desire to construct a collective, institutional authority. ${ }^{16}$

A final substantive point merits mention. The authors repeatedly emphasize that civil and common law systems differ in the structure of their highest courts, with civil law courts in particular reducing judicial identifiability and proscribing public dissent in order to buttress the collective authority of the institution, and common law courts being nearly invariably designed with an emphasis on public individual opinions and dissents. And yet, the authors are somewhat dismissive when interviewing international judges who have raised this point; only buried in a footnote ${ }^{17}$ do they suggest that judicial transparency might emanate from a domestic tradition. To my mind, this is illustrative of the somewhat decontextualized approach the authors have adopted; it ignores legal culture, and the

\footnotetext{
${ }^{12}$ Id. at 234 .

${ }^{13} \mathrm{Id}$. at $251-52$.

${ }^{14}$ South West Africa (Eth. v. S. Afr.; Lib. v. S. Afr.), Second Phase, 1966 ICJ ReP. 6 (July 18).

${ }^{15}$ It is also possible, of course, that the Court's Revision of its Rules coincided with a period of inactivity because it was only during such a period that the Court would have had the space necessary to embark on such a substantial revision.

${ }^{16}$ See the claims by Claus-Dieter Ehlermann, Reflections on the Appellate Body of the WTO, 97 ASIL Proc. 77, 78 (2003) (emphasis added), cited in Dunoff \& Pollack, supra note 1, at 266.

${ }^{17}$ Dunoff \& Pollack, supra note 1, at 234, n. 36.
} 
potential of a specifically international legal culture. But more than that, it does not give due regard to the systemic role a judicial institution will play within a legal order. The tradition of dissent in common law jurisdictions does not derive merely from tradition; in these jurisdictions, judicial decisions contribute directly to the development of the law; the decisions of the highest courts are in particular a primary source of law! In civil law systems, where in principle, law emanates from the will of the legislature, the judicial function is perceived not to create law, but to arrive at the correct interpretation or application of law. This is a caricature, to be sure, and both these dominant traditions have developed techniques along the way that make them resemble one another in practice. However, to my mind, the judicial role in law-development, and within the legal system more generally, would have probably served to modify the Judicial Trilemma from its present form.

\section{Final Reflections}

Dunoff and Pollack conclude both with a concession towards the need for context in relation to international judicial institutions, but equally so, a plea favoring their conception of judicial independence, advocating in particular for publishing separate and dissenting opinions. ${ }^{18}$ As a normative claim, they are careful to suggest that this is not a logical corollary of the Judicial Trilemma, which is essentially descriptive in forcing a choice between their three priorities of independence, transparency, and accountability. That seems perfectly reasonable, and a welcome concession from the authors. It feels, however, as though the Judicial Trilemma, and the lens through which it teaches us to analyze the workings of international courts, is itself selective. It privileges three particular values, suggests that they are the essential and unavoidable values involved in judicial decision-making, and in that act of privileging, excludes any number of further values. It presumes their objectivity, their universality, and their abstraction. Seeking as far as possible to engage with the inner logic of Dunoff and Pollack's article, I have alluded to two further values, systemic coherence and the authority or status of the institution itself that find a basis, broadly speaking, in the rule of law discourse in which the authors are immersed. But the Judicial Trilemma decontextualizes institutions and distances them from a number of further key values that have historically framed international judicial discourses, that make unique each institution, and that cannot easily be reconciled within its structures. For the ICJ, it is that enduring struggle between consent and universality, with the effects of decolonization and North-South relations sitting in a legally incommensurable, yet constantly palpable, way. For the European Court of Justice, an avowedly integrationist perspective towards Europe and the entrenchment of a European collective consciousness have been paramount in its work. Finally, the WTO has deeply embedded structures that privilege a certain neoliberal ethos of free trade, with minor concessions to human rights and the environment embedded firmly within that approach. One of the issues I have with The Judicial Trilemma is not that it is incorrect or insufficiently grounded, but that it draws attention away from those political dimensions where the true battlegrounds lie, and which are specific to each judicial institution. Perhaps it is just a question of focus, and again, I commend the authors' admirable engagement with the difficult methodological issues concerned; but in the quest for greater understanding of international judicial processes, more, and not less, context is crucial.

${ }^{18} \underline{I d}$. at 274. 